\title{
The Altai Cossacks family in the 19th - early 20th centuries: sociocultural and historical Aspects
}

\author{
Natalia V. Bitter ${ }^{I}$, Viktor V. Isaev ${ }^{2 *}$, Olga.V. Tiskova ${ }^{3}$, Natalia Yu. Buhner ${ }^{3}$ and Aleksandr N. Dunets ${ }^{1}$ \\ ${ }^{1}$ Altai State University, 61 Lenina St., Barnaul, Russia \\ ${ }^{2}$ Altai Branch of Russian Presidential Academy of National Economy and Public Administration, 187 Partizanskaya St., \\ Barnaul, Russia \\ ${ }^{3}$ Polzunov Altai State Technical University, 46 Lenina St., Barnaul, Russia
}

\begin{abstract}
The article is devoted to a brief history of Siberian Cossacks in Altai. The exploration of Altai by the Siberian Cossacks was conditioned by the political and economic interests of the Russian state. It needed to protect the southern borders of Siberia from aggressive attacks of the Dzungarian Khanate and to develop the natural resources of the Altai, primarily the ore deposits. During the development of this territory, the Cossack family was the basis of Cossack's life, a kind of financial, spiritual, and cultural center. When we considered transforming the Cossack family, we took into account the historical and sociocultural context. Various aspects describing the Cossack family are supported by statistical research data, in particular the 1917 agricultural census, a unique document that presents questionnaires of $95 \%$ of the Cossack households. An important place is given to the description of the rites and wedding customs of the Altai Cossacks, in which the traditions of Russian national culture are manifested.
\end{abstract}

\section{Introduction}

Yermak undertook a campaign to the Siberian khanate in 1581-1585, after which the Western part of Siberia became part of Russia. Only Altai territory - the southern region of Western Siberia - remained under Dzungar Khanate control.

In the early 18th century, the Russian state had become stronger, therefore its offensives in Altai began more intensively. The political and economic interests of the Russian state contributed to that. First, it was necessary to protect the southern borders of Siberia from the aggressive attacks of the Dzungar Khanate. Second, it was necessary to develop Altai land and natural resources, primarily the ore deposits.

In the 2nd quarter of the 18th-century, the Siberian Cossacks were transferred to the Altai to protect the Kolyvan-Voskresensk plants and were involved in the military service on the Kolyvan-Kuznetsk defensive line. Subsequently, they began to live in Altai permanently for two reasons. First, in 1747 Demidov's factories became the property of the Cabinet of Her Imperial Majesty. Second, the construction and development of the defensive line began. Thus, in 1751 the number of the Cossacks in the Altai territory was 1,337. From 1764 to 1771 a new line of fortifications, called the Biyskaya Cossack line, was constructed in the Altai. This line, along with the Presnogorkovskaya and Irtyshskaya lines, became a reliable defense of the Russian lands in the south of Western Siberia [1,2,3].

\section{Materials and Methods}

We used a set of scientific methods. This allowed us to consider the process of development of the Cossack family in Altai in the historical dynamics of socioeconomic and political processes that took place in the country.

The narrative method made it possible to describe in detail the wedding ceremonies of the Siberian Cossacks in Altai, reflecting the traditions of Russian national culture.

The chronological method allowed us to trace the main stages of the Cossack family development through the prism of the historical events that took place in Altai in the 18th - early 20th centuries.

During the 18th - the first half of the 19th centuries, the Cossacks were the Russian first settlers in this territory, representatives of the military estate, designed to ensure the safety of a small Russian population and enterprises of the mining industry.

Active modernization processes in Russia affected the Siberian Cossacks in the second half of the 19th early 20th centuries.

The state policy, aimed at expanding economic opportunities for Cossack households, had a positive effect on the Cossack family, which gained financial stability during this period.

The progressive process of Cossack family development was interrupted by the Civil War and the subsequent establishment of Soviet power, which led to the liquidation of the Cossacks as a special group within 
the social structure. And as a result, the basis of Cossack culture - "family as a value" - was lost.

\section{Results}

During the Altai colonization in the 18th - 19th centuries, the Cossack family was an important part of the Cossack society, a kind of life core. At the first stage, there was an acute shortage of women, which made it difficult to create a complete Cossack family. In the Siberian Cossack Host, it was solved in two ways: 1) by sending "colodniza (women exiled to Siberia for crimes)" to the defensive lines, 2) by stealing brides from the Kazakh clans. The above-mentioned actions occurred quite rarely in Altai. As a result of the transition of peasant and soldier families to the Cossacks, as well as the marriages of Cossacks with representatives of these families the number of women had increased significantly in Altai. In 1846, under the new Regulations on the Siberian Linear Cossack Host state peasants from 42 settlements of Kurgan, Ishim, Omsk districts of Tobolsk province and Biysk district of Tomsk province became Cossacks; the latter directly joined the ranks of the Altai Cossacks [4].

In the first half of the 19th century, Cossack settlements in Altai were scattered along the defensive line from Ust-Kamenogorsk to Kuznetsk. In 1848 the Kuznetsk-Biysk section of the defense line was abolished, and the Cossacks, numbering 3,030 men, were turned into peasants. Some of the Cossacks in the 10th Cossack Regiment moved to Semirechye due to the formation of the Semirechensk Cossack Host in 1867. In the second half of the 19th century, the problem of women's shortage had already lost its relevance.

In 1879 out of 6,733 people $(3,233$ men and 3,500 women) of the Cossack line $49.75 \%$ ( 3,350 people) were married, $43.1 \%$ (2,901 people) were single and unmarried, and $7.15 \%$ (482 people) were widows or widowers. The population in the Stanitsas was as follows. In the Antonievskaya Stanitsa (7 settlements, 2405 people: 1166 men and 1239 women) $59.7 \%$ of Cossacks were married, single men were about $34 \%$. In Charyshskaya Stanitsa (5 settlements: 1208 men and 1294 women) and Verkh-Aleyskaya Stanitsa (8 settlements: 859 men and 967 women) the married male and female comprised $43.2 \%$ and $45.6 \%$ respectively, the groups of single men and women were more numerous $-48.1 \%$ and $48.2 \%$ respectively. Such a numerical difference was primarily because that Antonyevskaya stanitsa and the settlements it comprised were closer to Biysk, the major commercial and industrial center of Altai. It was easier to organize personal life in this densely populated area than in the Charyshskaya or Verkh-Aleyskaya Stanitsas located in the foothills of the Altai Mountains [10].

In the 19th century, the Cossack family was small. According to data from 1884, there was an average of 2.3 men per the Altai Cossack family. Since the second half of the 19th century, Altai Cossacks practically did not marry peasants and representatives of the lower social classes. When marrying, they tried to take wives only from Cossack villages and settlements. It was an unheard-of event to marry a "muzhik" (a man from the peasantry) or to marry a "muzhicka"(a woman from the peasantry).

F. Zobnin's ethnographic essay, which traveled through Ust-Kamenogorsk Uyezd in 1897, gave a fairly complete picture of the Altai Cossacks wedding rites and customs. Although by this time the Cossack settlements of the Biysk line were not part of the Uyezd, the historical past linked them quite firmly. Before 1878, the villages of Borovskoye, Sekisovskoye, Verkh-Ubinsky and Plosky were part of the Ust-Kamenogorsk Stanitsa [6].

A wedding in Cossack villages, like a traditional Russian wedding, included many common and ceremonial acts. They were the matchmaking, the betrothal (zaruchenie or rukobitie), the bachelorette party, a gathering, and wedding reception. A wedding reception consisted of a Big Table (for the parents, the newlyweds, and the members of the wedding train), a Second Table (for guests and relatives), and other drinking tables including a Hangover Table (a treat on the second day after the wedding).

The Altai Biysk Line Cossacks were especially notable for their freedom of choice, where no one was "forced to be married" [7].

Then came the rite of betrothal (zaruchenie or rukobitie). The matchmakers came and asked: "What was said, what decision was made?" The bride's father answered, "The bride wishes, her relatives have advised her, come in the evening for a betrothal!".

Having received a positive answer, the matchmaker took the hands of the bride's father and mother (rukobitie) then the bride's parents agreed about a bride price payment (pod'iem), and gifts.

The most common gifts were: scarves (for the bride), a robe and boots (for the bride's father), a fabric for a dress (for the bride's mother), boots (for the bride's brother), a shawl (for the bride's sister), etc. Moreover, the bride's parents were presented with vodka in a quantity ranging from a quarter to a bucket.

In the evening, the bride's father and mother invited all their relatives and the matchmakers to their house. They discussed all the particulars of the upcoming wedding celebration.

At this time the bride, who was surrounded by young boys and girls, weeping with lamentations, mourned her maidenhood, farewell to her family, etc.

Meanwhile, the groom's father was engaged in the important matter of putting together the wedding train. The train consisted of the following persons (the members of the wedding train): a groom's godfather (a tisyatskiy), a groomsman (druzhka), a groomsman's assistant, two boyars, a matchmaker, and a driver (for the matchmaker and the bride).

On the day appointed for the bachelorette party, a bathhouse was heated by the bride's parents, then the bride with her bridesmaids, and the matchmaker went there. The bride's father, having invited his relatives to the bachelorette party. Then the groomsman and the groom and the members of the wedding train went to the bride, carrying gifts and wine. 
When the groomsman came to the door, he said the "Lord's Prayer" three times and waited for the bride's father to say "Amen" all the visitors entered the house. Stopping in the room, the groomsman asked the bride's parents for their blessing, after which the feast would begin. The matchmaker took the bride by the hands and led her to the table with the groom.

The groomsman still played an active role. Together with the bride's father, they served beer or wine to relatives, starting with the nearest and oldest, using glasses (drinks).

Afterward, everything went on as usual until each guest got up to five or six drinks. It was called a ryadovka (ryadovka is to treat guests with wine or beer once). Later, during the rukobitie, alcohol was counted in ryadovkas. Wine and beer were served by the groom this time, while the bride's side (her relatives) relied on snacks and tea. In some Siberian Cossack settlements, it was customary for the matchmakers to treat the bride's family until the bride said "Enough!". The guests sat at the tables until the Kurnik (chicken pie) was served. As soon as this dish was served, the guests thanked their father and mother for the treat and left the table.

The groom followed the bride, who, as required by the wedding custom, removed from the guest's view to the Kut (the women's place in the house, in front of the stove). Here he presented her with a shawl, headdress, boots, and earrings. The groom was followed by the groomsman and the members of the wedding train. There were no definite rules about the gifts: everyone bought a gift according to his or her wealth. After that some gifts were presented to the bride's parents, brothers, and sisters, as agreed at the betrothal. When this ceremony was over, the bride's father and mother invited the groom to the "crossing".

During the bachelorette party, when the guests sat at the tables, the maidens surrounding the bride sang a chorus prescribed by customs songs, for which the guests had to give the maidens money.

On the eve of the gathering and church wedding ceremony, the members of the wedding train entertained at the groom's home. The groom's mother heated the bathhouse, in which all the guests were bathed and steamed together with the groom. This kind of washing had the character of a special ceremony. Before bathing, the groomsman addressed the groom's father and mother with the words, "Lord Jesus Christ Son of God, have mercy on us! Dear father, dear mother! Bless your dear son to the steam bath to be washed and cleaned!" The parents answered, "God bless!" after which the guests went to the bathhouse.

Returning from the bathhouse, the groomsman again addressed the groom's parents: "Thank you, father and mother, for the steam bath, for the spring water, for the silk brooms!". After these words, the guests were treated with wine and dishes, and then the horses, harnesses, and carriages (wedding train) were prepared for the next morning's journey to the bride and the church wedding ceremony.

In the morning, the members of the wedding train and relatives gathered for the "provodini" (seeing the groom's off). The groom had to get his parents' blessing before he left. The groomsman addressed the groom's parents: "Dear father, dear mother! You have managed to feed, to dress, and to send your dear child to work. Bless him on his way to the Church wedding ceremony". The father and mother answered, "God bless!" gave the groom their blessing. The blessing consisted of the following: the groom's parents went to the table, took an icon, bread, and salt, and blessed the groom with the icon and bread and salt across the table. At the time of the blessing, guns were supposed to be fired in the room and the yard.

The groom's relatives gathered at the wedding ceremony and sang songs: "Whose stableboys are out in the meadows? / They are embedded in silk and silver, / Our stableboys don't eat silk grass, / Our stableboy don't drink spring water, / Our stableboys apprehend a long way to berry picking in the forest / Choose, my child, the best berry / Choose, my child, the best girl / Choose the best girl, Stepan Mikhailovich, for yourself / The most beautiful / Akulinu Ivanovnu".

After the blessing, the groomsman transmitted the groom and guests out into the yard and said: "Dear father and dear mother, old men with grey beards, old women, young men, and young women, red maids with naughty masters and little guys! Bless us for the church wedding ceremony!". The crowd responded in chorus: "God bless!". The gunshots rang out again. The wedding train moved in the following order: first - the groomsman and groom's friends, second - the boyars, third - the groom with his godfather, and fourth the matchmaker with the driver. It should be mentioned that the members of the wedding train were dressed especially on that day. All wore a shawl around their necks which crossed over their chests. In addition to the shawl, the groomsman had a whip around his waist.

On entering the bride's yard, the matchmaker greeted the guests with a glass of wine. The bride's father blocked the entry by holding the door from the inside. The groomsman stood at the door and said the "Jesus Prayer" three times, and after the bride's father said "Amen" and the groomsman replied, "Amen save and have mercy". Then everyone entered the house. At this time the bride was already seated at the table. She was surrounded by a matchmaker (the bride's godmother), the bride's brother, and her girlfriends, who helped her to sew outfits and dowry, and to mourn her maidenhood.

Then the so-called "bride's plait buying out" was performed. The groomsman would take a whip and use it to scare the bride's bodyguards away from the table. At first, he attacked (jokingly) the bride's brother: "Why are you here? Go away, or I'll lock you up!". He defended himself as best he could, but didn't leave his seat at the table. The groomsman was tricky; he offered the bride's brother a glass of wine, but he refused. Then the groomsman added a ruble of money to the wine for the bride's plait, and her brother agreed; he drank the wine, took the money, and left the table. The bride saw it and started to cry out: «My dear brother! You traded my plait for money».

After agreeing with the bride's brother, the groomsman turned to the maidens: "What do you want? What are you waiting for? " - "We want payment for our 
work" - the maidens replied. The bride's father determined the amount of money or the cost of maidens' gifts during the betrothal. So the groomsman was aware of the maidens' desires but still tried to get away with a glass of wine, which he gave to the maidens. Only when he saw that the ruse was not working he gave money or gifts. The maidens drank wine from a common glass, took the money, and left the table, leaving the bride alone.

After the table had been cleared, the groomsman invited the guests to the table and seated the groom near the bride. The gifting started. The bride's father and mother were the first to be given a gift. -3 roubles for the father, fabric for the mother. Then other bride's relatives were given gifts. The groomsman then said: "Dear father, dear mother! Please point out who is taller, who is closer to your heart, serve wine and treat the guests, so that they can talk more cheerfully!».

All the bride's relatives, as well as, guests were gathered at the bride's house by this time. The groomsman treated the bride's relatives, old and young. The old men who could not drink poured the wine into a spare cup. After that, the groomsman treated the rest of the guests to wine, but no more than three times.

The maidens sang sad songs, because of the near parting "with a favorite girlfriend" and the difficult family fate awaiting her.

When the treatment was over, the groomsman asked, "Are all the guests happy?". The matchmaker responded, "Happy!" and the groomsman directed the matter further. He again said the "Jesus Prayer" and then asked the parents to bless the bride and groom in the same terms he had used to address the groom's parents above.

To receive a blessing, the bride and groom would leave the table on a special carpet in front of the table, and the parents would go behind the table and from there bless with an icon and bread and salt. At the end of the blessing, everyone went out into the yard or street to the wedding train, the bride was helped to sit down by the groom, and the matchmaker by the groom's godfather.

The groomsman and the groom's friends circled the horses three times, reciting the "Sunday prayer" as the guests took their seats on the wedding train. This prayer was considered a sure way to exorcise evil spirits. Then, after finding out if everyone was in place, they gave the order to leave.

The groomsman gave the bride's father a bottle of wine (vodka) before he left. When leaving the village, the maidens got off the wedding train and returned to the bride's house. The groomsman returned with the maidens and said to the bride's father, "The children bowed down, stayed alive and well!". The father, who received such happy news, hurried to treat the messengers with wine (vodka) - it was supposed to drink a glass or two. The messengers drank, gave thanks, and drove off to the wedding train, which waited for them outside the village.

The members of the wedding train, if the church was far away, would "put on warm bast shoes" (drink alcohol) before setting off on their next journey. After driving a few versts, the groomsman would say to the members of the wedding train, "Guys! It's time for a warm-up! - and, having received a friendly agreement, took out the alcohol he had saved and offered it to all who wished. Such stops were repeated depending on the length of the trip.

The wedding train followed the following order on departure to the church: groomsman with friends, boyars, tisyatskiy (the groom's godfather) with the groom, and the bride with a matchmaker and a driver. The order of the wedding train on the way back from the church changed-the newlyweds rode together, and the tisyatskiy (the groom's godfather) with the matchmaker.

On the way out of the church, the wedding train stopped before reaching the village. The groomsman and his assistant would go to the groom's home to see his father and mother, to whom the groomsman would report, "Thank God the children are alive and well".

The groom's father treated them with wine. Then the groomsman returned to the wedding train and go with its members to the parents' house.

The father and mother blessed the newlyweds once again at the porch.

Then the matchmakers braided two braids for the "young woman" (unmarried maidens braided one braid, thus braiding two braids meant the transition to married life) and then put on a headscarf. This "okruchivanie" (a rite symbolizing a change in a maiden's status and her transition to the married woman status) of the young woman took place secretly from the guests, under the cover of a stretched shawl.

While the "okruchivanie" was going on, the groomsman's assistant went to the bride's house to get the bride's linens, which were then prepared by the matchmakers. The groomsman turned to the groom's parents: "Dear father, dear mother, dear mother! Bless our young prince with a young princess to lay his "lawful married bed!".

The matchmaker and the groom's godfather were present when the newlyweds went to their "lawful married bed", also when they undressed, making sure that the newlyweds were wearing clean underwear. F. Zobnin noted: "The inhabitants looked at the bride's chastity from a conventional point of view, giving importance to the demonstrative side, for the elders, and other wedding guests as well, there was at the first place an unembarrassed wedding fun, which is only possible when everything goes quietly and smoothly" [6].

In the late 19th and early 20th centuries, remaining chaste was no longer considered a mandatory requirement for brides. In 1899, 167 children were born, including 4 from "illegal cohabitation" in Charyshskaya Stanitsa, which consisted of 5 settlements [7]. There were 8 illegitimate births out of 202 children born in 1900 [9].

Then the wedding party began. The newlyweds were greeted with cheers. Newlyweds treated parents and the members of the wedding train to wine. The bridal shirt was tied in a shawl, and the groom's father and mother and wedding train members rode with songs and red scarves on the harness to thank their father-in-law and mother-in-law for bringing up their daughter. They took no less than two shofars of vodka with them.

Then the newlyweds invited their relatives to the wedding party. The "Big Table" at this feast was made 
up of the newlyweds and their parents. It was served by a groomsman himself. After a few drinks (about 3-4), the newlyweds came out from the table and took the wine. Initially, wine was presented to the young husband's father and mother. The father drank and gave a dowry, usually a horse, the mother a cow; the same gifts were given by the father-in-law and mother-in-law. The closest relatives of the newlyweds brought a calf, a sheep, money, or even a chicken as a dowry. It depended on the wealth and personal attitude toward the newlyweds. Then they treated the wedding train members. When the newlyweds offered the glass, they bowed to the ground and stood on a bow until the one who accepted the wine appointed a dowry. The newlyweds sat down at the table after they had served their parents and the members of the wedding train one at a time. When the refreshment was over, the bride's representatives said, "That's enough". After that, the cook treated everyone with wine, for which she was given small money - one or two kopecks.

The feast described above was called the "Big Table". The following dishes were supposed to be put on the big table: cold soups and starters; Kurnik, decorated with colored paper; fried meat, fried geese, ducks, piglet, decorated with colored paper; potatoes covered with eggs; pryazheniki (pies with meat), pashketiki (pies with different berries) as well as egg, carrot and rutabaga pies. Then various hot dishes were served: soups of meat, pork, poultry, but not less than three soups. Cookies and tea were served for dessert.

The guests gathered for the "hangover" table the day after the wedding. The groomsman and the members of the wedding train were engaged in treating. Dumplings were an indispensable part of the hangover table. After the hangover, the groomsman demanded a special table for himself and for the members of the wedding train, which was served by the newlywed's parents. In the end, the groomsman received a bottle of vodka, covered with a headscarf, and a Kurnik from the young wife. He carried it all home and invited the wedding guests after him.

The father-in-law would start the wine party with his son-in-law, who would drink wine with the bride from the same glass and taste the pancakes. Then the fatherin-law gave wine to the groom's father and mother, and the newlyweds brought pancakes. All the guests were treated in this way: the father-in-law treated them with vodka and the newlyweds with pancakes.

After the pancakes at the father-in-law's house, the party passed on to the families of his relatives. In the end, the last wedding table (ras'hozhii, which means, what after that all the guests went home, the wedding reception was finished) was laid and the young husband's father thanked his relatives and especially the new matchmaker for helping him to arrange the wedding properly, according to the law.

All wedding ceremonies required significant expenditures from the groom's family, which on average amounted to 100 rubles. "Significant expenditures were required:

- the bride's price payment (pod'iem) - 15 rubles;
- the gifts to the father-in-law -5 rubles, the motherin-law -2 rubles, the bride's brothers -2 rubles, the sisters -3 rubles, the bride - dress, shawl, scarf, shoes;

- buying alcohol and food: vodka, wine, beer 6-7 buckets, meat and butter, tea and sugar;

- paying for the church service: 7 rubles" [5, p. 24].

As a rule, the newlyweds moved out of the parents' house some time after the wedding and began to live in their own home (usually after 8-10 years after the wedding). Nuclear families consisting of a married couple (sometimes also the husband's elderly parents) and children prevailed among the Siberian Cossacks. Extended families (cohabitation of free blood relatives: parents, their married sons, and grandchildren) represented the minority. In the late 19th and early 20th centuries, a process of Cossack's families fragmentation had began. There were 606 families in the Charyshskaya Stanitsa in 1899 among them 60 families consisted of two people, 56 of three, 76 of four, 103 of five, 83 of six, and 228 of seven people [6, 8-9]. The changes are recorded in detail in the 1917 agricultural census questionnaires. According to these data, between 1862 and 1917 there were 518 separations of the Cossack households property. The intensity of this process was as follows: 1862-1885 - 20, 1886-1899 - 117, 1900-1913 $331,1914-1917$ - 48 separations of property.

The data indicated a growing process of Cossack families fragmentation, which was halted by World War I.

We could consider a typical young Cossack family using the example of the inhabitants of the Bobrovsky village of Verkh-Aleyskaya stanitsa. The average marriageable age for men was 24-25 years old and 21-22 years old for women.

The income of young families was low. For example, the Andreev family (Vasily and Irina, daughter Elena) separated into their household in 1912 after 2 years of living together with their parents. In 1917 they had 2 horses, 2 cows, a sheep, and a pig, 10 tithes ( 1 tithe $=1.09$ ha) of arable land, and 2 tithes of meadowland. They sowed 1.3 tithes ( 0.9 of spring wheat, 0.3 of oats, and 0.1 of potatoes). The head of the family, Vasily Andreev, rented farming equipment (a plow and a harrow) from his brother.

Over time, the income of Cossack families increased significantly. Analysis of the 1917 agricultural census questionnaires showed that on average there were 6 horses and 9 head of cattle per Cossack household, while in the peasant farms their number was markedly lower and was 4 and 5, respectively. The technical equipment of Cossack households was extremely high, far ahead of the local peasants' households [10].

At that time there were 2,100 households on the Biysk Cossack Line, representing 12,096 Cossacks. On average, there were 5.8 people per household, i.e. a Cossack family averaged 6 people. Large families were widely respected and were the pride of Cossack settlements. For example, a 61-year-old Cossack Ivan Yerofeyevich Kazantsev, the head of a large family, lived in Terskaya village. Together with him lived 21 people - his wife, brother, 4 sons, 4 daughters-in-law, 3 grandsons, 6 granddaughters, and a worker [1]. 
The Revolution of 1917 and the fratricidal Civil War that followed dealt an irreparable blow to the Cossack family, destroying many Cossack traditions and customs.

On December 2, 1919, by order of the Siberian Revolutionary Committee, the Siberian Cossack Host was abolished. Cossack Stanitsas were losing their former administrative independence and were included in the peasant districts. This inevitably led to the destruction of the Cossacks' traditional way of life, destroying family traditions and customs that had been formed over the centuries.

\section{Conclusion}

The Cossack family as a socio-cultural phenomenon was formed in Altai during the 18th and early 20th centuries.

At the first stage (18th - first half of the 19th centuries there was an acute shortage of women, which made it difficult to create a complete Cossack family. It did not allow to make a full-fledged Cossack family. In the Siberian Cossack Host it was solved in two ways: by sending "colodniza" or by stealing brides from the Kazakh clans. The above-mentioned actions occurred quite rarely in Altai. The increasing number of women was due to the transition of peasant and soldier families to the Cossacks, as well as the marriages of Cossacks with representatives of these families.

In the 19th century, the Cossack family received new development opportunities. This was due to several reasons: first, the abolition of serfdom in Russia in 1861, and second, the reform of the Siberian Cossack Host, which resulted in reducing the duration of military service and providing opportunities to their engaging in economic activities.
The economic potential of Cossack families and their income were significantly more than the income of Altai peasant families.

In the late 19th-early 20th century, as capitalist relations developed among the Siberian Cossacks, there was a process of families fragmentation, which was interrupted by World War I, followed by the 1917 Revolution and the Civil War.

The establishment of Soviet power in Altai caused the destruction of the Cossacks' family cultural and historical traditions.

\section{References}

1. V.V. Isaev, The Cossacks of the Biysk Line in the Revolution and the Civil War. 4-5 (2004)

2. V.V. Isaev, Archaeology, Ethnography, and Anthropology of Eurasia. 1 (2010)

3. V.V. Isaev, A.N. Dunets, Grand Altai Research \& Education. 2. (2015)

4. Historical Archive of the Omsk Region. Fund. 67. In. 1. F. 525. P. 19-20.

5. Historical Archive of the Omsk Region. Fund. 67. In. 1. F. 1305. P. 308-310.

6. Commemorative book of the Semipalatinsk region for 1900. 4 (1900)

7. M. Minenko, Rodina. 5, 118. (2004)

8. State Archive of Altai Krai. Fund. 216. In. 1. F. 26. PP. 8-9, 17-19.

9. State Archive of Altai Krai. Fund. 216. In. 1. F. 31. PP. 15-16.

10. State Archive of Altai Krai. Fund. 233. In. 1a. F. 52-54, 292, 619, 632, 633, 777-784; In. 1b. F. $123-129,452-454$. 